\title{
Mezi folklorem a uměním, mezi zeměmi a existencí
}

\author{
LIBOR PAVERA \\ Univerza v Bielskem-Biali, Fakulteta za humanistiko in družbene vede, Ul. Willova 2, \\ PL-43-309 Bielsko-Biała, lpavera@ath.bielsko.pl
}

SCN II/1 [2009], 95-105

Prispevek obravnava avtorico, ki je živela in ustvarjala na geografsko-jezikovno-kulturni meji, kar se kaže v njenih delih, umeščenih med leposlovje in folkloro. Avtor opozarja tudi na uporabo zgledov, čas in prostor ter topiko prostora.

The author deals with a writer who lived and wrote on a geographical borderline, as well as on linguistic and cultural borderlines, which is reflected in her work. It is placed between artistic literature and folklore. The author also considers several special motifs, e.g., the use of exemplum, time and space and the topic of place.

Ključne besede: folklora, leposlovje, odnosi med folkloro in umetnostjo, pripovedništvo, topos

Key words: artistic literature, folklore, relationship between folklore and art, narration, topoi

\section{Hledání a poznávání tranzitivních zón}

Obecně lze říci, že z vnějšího pohledu v Evropské unii probíhají především sjednocující, unifikační tendence. Ale tyto unifikační tendence vyvolávají rovněž síly protichůdné, různé intenzity, jež navíc ve výsledku mají určitá pozitiva i negativa. Jedním z pozitiv je vytváření tzv. euroregionů a to, že se ve vědě začal klást důraz na poznávání míst na hranici, tranzitivních zón: v podstatě se propagují regiony, „malé vlasti”, „kresy”, cosi „okrajového” a „hraničního”, co dříve bylo vulgárně a nesprávně nazýváno periferií. Mění se vztah mezi centrem a okrajem, zejména pod vlivem žánrů elektronické komunikace, jež vlastně v pozici výrazného informačního prostředníka umožňuje stírání rozdílů mezi centrem a periferií a jejich zrovnoprávňování, nebot' i z místa na periferii lze ovládat a ovlivňovat centrum; uvažování v kategoriích centrum a periferie 
se tak jeví nejen jako značně problematické, ale již i nepatřičné. Vůbec s ním pak již nelze pracovat v oblasti axiologické (např. př̀i hodnocení textů v kritice literatury nebo v literární historii). Zájem je tak nejen o artistní tvorbu (umělou či uměleckou literaturu), ale i o projevy folkloru. „Ostatnio rośnie zainteresowanie przeszłością kulturową Europy, szukamy współnych korzeni, tego co nas łączy, współnych systemów odniesienia, współnych tradycji. Coraz więcej powstaje prac na temat cywilizacji i tożsamości Europy. Osobom nie zajmującym się folklorem trudno uwierzyć, iż najwięcej materiałów do europejskiej tożsamości znajduje się w opowiadaniach ludowych" (Simonides 2006: 55).

Mohutný a ve vědě výrazný návrat k místům na hranici a k místům „mezi” se ukazuje být nesmírně plodný, nebot’ ve výsledku poukazuje na jevy neprávem zapomínané, opomíjené a mylně interpretované. Ve vědě o literatuře tak objevujeme množství nesmírně zajímavých původních autorů, ale i sběratelů folkloru, kteří byli mylně považováni za „okrajové”, „málo nosné”, „regionální”, „zatížené folklorem” apod. Současná proměna v chápání míst na okraji nebo míst „mezi” je zároveň výzvou nejen pro literární historii, ale i pro literární teorii a metody literárněvědné práce.

\section{Autorka žijící „mezi”, „na hranici” světů}

K autorkám, které nejen fyzicky, ale i ve světě představovém žily v neustálém časoprostoru „mezi”, jako by rovnou ,na hranici” několika světů, patřila Ludmila Hořká (narozena 26. 4. 1892, Štítina /osada Dvořisko, dnes Kravaře-Dvořisko u Opavy/, zemřela 4. 10. 1966, Opava). Byla nejen prozaičkou, ale daleko dř́ve, než začala psát umělou, artistní tvorbu, sbírala folklor v celém spektru jeho žánrů (pořekadla, písně, tance), psala básně (zprvu pod silným vlivem poetiky folkloru) a sama byla rovněž lidovou vypravěčkou - narátorkou.

Původně se jmenovala Marie Šindelářová, pseudonym si zvolila podle svého osudu - ten byl hořký, tedy pojmenovala se „hořká”. Po celý svůj život, s výjimkou několika cest, které vykonala nejčastěji do Prahy (zejména do rozhlasu) nebo do větších měst, žila v oblasti Hlučínska. Byl to kraj a dodnes je to kraj poněkud zvláštních osudů. Hlučínsko patřilo kdysi Habsburkům. Náleželo do Slezska, což byla od 16. století jedna z nejbohatších habsburských zemí. Zejména se zde zpracovávaly látky, textilie, které se odsud vyvážely do Holandska a jiných západních zemí. Když císařovna Marie Terezie prohrála část habsburských držav ve slezských válkách, ztratila roku 1742 v tzv. vratislavském míru celé toto území, resp. došlo k jeho dělení. Malou část Slezska panovnice sice ještě získala zpět, avšak většinu území získal pruský král. Zisk pak Prusko potvrdilo ještě ve válce sedmileté (1756-1763). Došlo k dělení území, ale na rty se přímo tlačí sugestivní otázka: mohl být při politickém a správním dělení rozdělen také člověk se svými myšlenkami a pocitovým světem, rodiny, určité společenství? Mohly být válečnou smlouvou rozděleny také tradice, kultura, folklor? Je jednoduché scelovat, unifikovat, ale daleko složitější je rozdělovat ... Existuje zde právě tradice, cosi společného jedincům žijícím v jistém prostoru a čase, 
např. právě folklor, který zpravidla bývá nejtypičtějším znakem, signifikantem určité oblasti a jejích obyvatel. Tradice vytváří spolu s jinými znaky společnou pamět' místa, která se jen tak snadno nevytrácí z lidského vědomí; užít lze $\mathrm{v}$ této souvislosti rovněž termínů kolektivní pamět' nebo sociální pamět'. Kontinuuje v lidských dějinách - a často po velice dlouhý časový úsek - poselství určité society. Společná pamět’ místa je ponorná řeka: dokáže zmizet ze scény, ale stejně rychle svede $\mathrm{v}$ jistém okamžiku vytrysknout na povrch a přinést na světlo prvky již zdánlivě odumřelé, a i když se na prvý pohled jeví, že místo není živou bytostí a nemá pamět', zpravidla tomu tak nebývá (vzpomeňme na to, jak se některé příběhy původně $\mathrm{z}$ umělé tvorby dostaly do folkloru a pak již jako folklorní vrstva zůstaly - dokonce v cizojazyčném prostředí - prrítomným fermentem kultury po dlouhý časový úsek a po létech byly zapsány jako rezidua ústní lidové kultury a znovu se staly součástí artistní, umělé literatury).

Autorka, o jejichž textech se stručně zmíníme, žila tedy v oblasti „hraniční”, „mezi” dvěma císařstvími, rakouským a německým (pruským). V oblasti, kde si ruce podávaly různé národnosti, různé kultury, kde docházelo k vzájemnému dialogu, o němž samozřejmě obecně platí, že nemusí fungovat jako skutečný hlasitý dialog, ale může mít i podobu mlčení - vždy podle konkrétního dobového kontextu.

Co víme o Hořké z její biografie? Hořká byla dcerou hostinského. Veliké vzdělání neměla, chodila do dvoutřídní obecné školy, nejdříve německé v Kravařích, pak do české ve Štítině. Krátce navštěvovala také rodinnou školu. $\mathrm{V}$ devíti letech jí zemřela matka a po otcově novém sňatku vyrůstala u tety v Kravařích a již tehdy pomáhala $\mathrm{v}$ otcově hostinci, který později po smrti otce rovněž po několik desítek let vedla (1915-1958). Na počátku dvacátých let se stala členkou a pak i vedoucí pobočky národopisného sdružení Sedlištané v Kravařích za přispění etnografư Jana Vyhlídala a Františka Myslivce sběratelkou písňového a slovesného folkloru (srov. Satke 1968, 1972, 1986, 1993 aj.).

Prožila dvě světové války, dvakrát se provdala, její manžel zedník byl často bez zaměstnání (zejména po r. 1929 v době hospodářské krize) a rodina $\mathrm{s}$ jedenácti dětmi často trpěla bídou (Hořká vedla sice hostinec, ale německy smýšlející obyvatelstvo Dvořiska její hostinec bojkotovalo, nebot' bylo obecněji známo, že Hořká přispívala do českých novin). Po záboru pohraničí v říjnu 1938 se uchýlila do Kostelce na Hané, po deseti měsících se vrátila do Dvořiska. V souvislosti se svou předválečnou činností byla krátce vězněna v Opavě a mnohokrát vyslýchána - někdy lidmi, kteří ji udávali v době první světové války nebo v době mezi válkami ...

Nejprve začala Hořká ve dvacátých letech 20. století uveřejňovat sběry lidové slovesnosti: písně a pohádky; později pak přibývá i vlastní lyrika, spíše ohlasová (vydal ji posmrtně Antonín Satke, srov. Hořká 1992). Její tvorbou lze listovat v časopisech Moravec (Hlučín), České slovo, Náš domov (Opava), Radostná země (Opava) aj. V rukopise zůstala její sbírka více než stovky lidových písní z Kravař a Dvořiska a kronika osady Dvořisko.

Její romány tvoří svébytné, přesto vzájemně se prostupující celky: Doma klade na piedestal rodinu i zvyky a život slezské vesnice před vypuknutím první 
světové války, román rozšiřuje později knihou Dolina, kde si všímá nezájmu centra o periferii a postupného poněmčování oblasti „na hranici”, v Řece vypovídá o vesnici „na hranici” a „mezi” císařstvími, opět z vesnického prostředí je vybrán hlavní hrdina, německý voják, jehož životní osudy sleduje v románu Bílé punčochy. Mnoho autobiografických prvků je zachováno v jejích drobnějších prózách; právě u těch literární historikové poukazovali na četné spojnice s prózami Boženy Němcové, klasické autorky české literatury 19. století.

\section{Hořká v odborné literatuře}

O autorce již zasvěceně a informovaně psalo několik literárních badatelů: Antonín Satke (srov. zde oddíl literatura) se zaměřil zejména na práci Hořké $\mathrm{s}$ folklorem a na Hořkou jako vypravěčku a básnířku, prózám Hořké se věnovali Drahomír Šajtar a Jiří Svoboda, zatím naposledy o Hořké vznikla syntetizující monografie Drahomíry Vlašínové (2008), přesto zůstává několik teoretických otázek, ke kterým je potřeba se vrátit v následujících poznámkách.

\section{Vztah folkloru a umělé literatury u Hořké}

Především nás musí zajímat vztah folkloru a umělé literatury. Předěl mezi folklorem a umělou literaturou není u Hořké výrazný natolik, že by bylo možno hovořit jednou o autorce Hořké-folklorní a podruhé Hořké-artistní. Zejména v jejích básních přechod takřka nepostřehneme. Ona sama nejprve zapisovala folklor, pak na základě folkloru začala tvořit básně - literární teorie říká takové tvorbě „ohlasy”; začaly vznikat v době, kdy J. G. Herder pobízel ke sběru a výkladům lidové písně, v níž spatřoval výraz národní duše - básníci pak tam, kde takovou lidovou píseň nenacházeli, přirozeně zaplňovali mezery pěstováním „prostonárodní tvorby”, v české literatuře je najdeme nejvýrazněji zastoupeny u F. L. Čelakovského (Ohlas písní ruských, 1829; Ohlas písní českých, 1839), K. S. Šnajdra, J. V. Kamarýta, J. K. Chmelenského nebo V. J. Picka-Podsvijanského, kteří byli v podstatě epigony ohlasové tvorby Čelakovského.

V této souvislosti je velice zajímavá korespondence Vladimíra Holana (19051980) naší autorce. Přední český básník Holan, známý v překladech rovněž v zahraničí, se s tvorbou Hořké seznámil teprve na konci padesátých let 20. století, v době, kdy to byl autor již evropsky oceňovaný. Není vůbec náhodné, že o knihy Hořké projevil zájem: méně se v literární historii píše o tom, že právě Holan s Františkem Halasem, dva představitelé nejartističtější ze své generace, sestavili z folkloru antologii Láska a smrt (vyšla v červnu 1938). Prostředníkem seznámení Holana s tvorbou Hořké byl Josef Vašica (1884-1968), kněz a profesor staroslověnského jazyka a písemnictví. Pocházel ze Štítiny ve Slezsku a k rodnému kraji se po celý život navracel - ve vědecké práci i fyzickými návštěvami. I tím, že autory spjaté s krajem propagoval mezi svými přáteli a blízkými. Měl kontakty na mnoho duchovně orientovaných spisovatelů (J. Čep, 
J. Durych, J. Zahradníček aj.), svědčí o tom bohatá korespondence (uložená v PNP v Praze), obraceli se na něj rovněž vědci a spisovatelé s prosbami o radu či duchovní útěchu. Jeho prostřednictvím se s Hořkou seznamuje Holan a v jednom z dopisů Vašicovi píše, že její knihy zůstanou „už proto, že nejsou literaturou!” Zastavme se u tohoto vyjádření: „Nejsou literaturou”? Cím jiným tedy jsou než literaturou? Co myslí Holan v obdobné souvislosti „démony”?

Ani jedno z tázání nemá jednoduchou odpověd'; stěží na ně odpoví jiný Holanův dopis, který se v pozůstalosti Hořké zachoval. Přesto musíme vyjít z mála nápovědí, jež zůstaly uloženy v korespondenci, a ze znalosti teorie folkloru a vztahů mezi folklorem a artistní tvorbou. Tou se zabývali v rovině praktické právě Holan s Halasem, když připravovali již uvedenou antologii Láska a smrt, v rovině teoretické pak zejména představitelé strukturalisticky orientované vědy Roman Jakobson a Petr Bogatyrev (srov. Bogatyrev 1971). Protože oba byli především lingvisty, využívali de Sausurovy terminologie (terminologie ženevské školy) a termíny langue a parol uplatnili analogicky na vztah literatury a folkloru. Zatímco pro folklor je podle jmenovaných teoretiků typický kolektiv a zaměření na langue (na existující normu), pro literaturu je specifické zaměření na parole, na individuální výpověd'.

\begin{tabular}{cc} 
langue & parole \\
\hline folklor & literatura \\
(norma) & (individuální výpověd')
\end{tabular}

Ale z textů jednotlivých knih Hořké je patrné, že se autorka zaměřuje spíše na langue. Svědčí o tom nejen splynutí cenzury a díla, což je jeden ze závažných znaků folkloru, ale její text bývá zpravidla i nadosobní, navíc u ní nejednou dochází k variacím na obdobné téma (Vlašínová v monografii o Hořké upozorňuje, že bereme-li ,do rukou kteroukoliv z autorčiných knih, ... obíráme se jen jednou částí, řekněme kapitolou, oddílem jedné velké knihy, knihy-cyklu ...,", Vlašínová 2008: 77). Podobně jako zpěvák, jak poznamenal slavista Matija Murko, nedeklamuje jen pevný, ustálený text, ale vždy znovu a znovu tvoří text nový. Hořká tvoří vlastně vždy obměnu, mutaci, variantu, nikoliv nový text. Chová se více a častěji jako tvůrce folklorní ...

Problematika vztahu mezi artistním x folklorním je však u Hořké ještě složitější, než aby bylo jednoznačně rozhodnuta jedna nebo druhá varianta, protože u ní z hlediska intertextuálního vidíme text rozložen do několika vrstev: jednak je to vrstva folklorních projevů (1), jednak vlivů folkloru na literární projevy (2) a konečně literární projevy adaptované folklorem (3). Tyto tři roviny se u ní střídají, některá z nich vždy v určitý okamžik vystupuje do popředí a stává se plánem vưdčím. Bude tedy v budoucnu nutno u každého jejího jednotlivého textu rozlišit, který plán převažuje nad ostatními. Z analýzy takto vytvořené může být kontrastivním studiem pěkně a plasticky ukázáno, jak se autorka folkloru vzdalovala či se $\mathrm{k}$ jeho kořenům navracela zpátky.

Nicméně z hlediska existence literárního a folklorního textu lze tu mluvit $\mathrm{v}$ obecné rovině o literatuře, tj. o zapsaných textech $\mathrm{s}$ intencionálním záměrem 
být textem artistním. Představme si situaci asi následovně: sopečný vulkán, chrlící žhavou lávu - folklor, kterou někdo v jistou chvíli ochlazením zastaví a petrifikuje do materializované podoby - textu.

\section{Problematika návratů}

Problém návratů - tak lze lakonicky pojmenovat další z látek, na kterou v tvorbě Hořké při podrobnější četbě jejích textů narážíme. Návraty a locus amoenus. Autorčina pamět' se neustále navrací do minulosti a selektuje. Vybírá ze své osobní paměti určité okamžiky, selektuje z celého korpusu podstatné a hodné zápisu - nejčastěji vzpomínky na dětství. Dětství, i když nebylo zcela štastné a idylické, je pro ni dobou štastných návratů, které se $\mathrm{v}$ její tvorbě neustále variují. Vrací se neustále k loukám kolem vody, vzpomíná na chvíle, kdy jako malá dívka pásala husy nebo si hrála s ostatními dětmi. A očima dětskýma, leckdy naivníma, pohlíží na tehdejší svět. Samožrejmě pamět' lidská není pamět' počítače - leccos se z ní vytrácí, leccos naopak s časem a přibývajícími léty v ní přibývá. Nejčastějším topoi je u ní nicméně locus amoenus. Tak vlastně - jako líbezné a štastné místo - vykresluje prostor, oblast, krajinu, ve které se jako dítě ve svých návratech snadno pohybuje a z níž (povětšinou jako statista) pohlíží na okolní svět.

V době, kdy autorka píše své knihy (prvotinu vydává 1943), má už medievalista E. R. Curtius hotovou svoji koncepci knihy Europäiche Literatur und lateinisches Mittelalter, kterou vydal po skončení 2. světové války a v níž má mimo jiné rozsáhlou kapitolu věnovanou loci communes - pojednání o tzv. topice. (V současnosti bývá zaměňována nesprávně $\mathrm{s}$ tzv. tematologií. Ale „vězení”, „kostel”, „hora” atd. nejsou typickými topoi v curtiovském pojetí, to jsou tematizovaná místa, „místa s tajemstvím”, řečeno titulem známého spisu teoretičky Daniely Hodrové; spolu s Paulem Van Tieghemem je tu opravdu př́ípadnější hovořit o tematologii.)

„Místo líbezné” - to není u Hořké jen místo v geografickém smyslu, je to u ní rovněž místo či status $\mathrm{v}$ psychice, je to stav psychického rozpoložení, momentální stav její duše. Místo líbezné je u ní schopné žít nezávisle na reálném, skutečném prostoru a čase; $\mathrm{k}$ němu se utíká $\mathrm{v}$ časech strádání nebo vnějšího ohrožení. Zůstává v její paměti a odtud se obměňováno dostává do jejích textů $\mathrm{v}$ různých variantách a variacích. Pochopitelně mechanismus návratů $\mathrm{k}$ „,místu líbeznému" se spouští povětšinou ve chvílích vnějšího ohrožení. Text se tak stává místem terapie z utržených traumat a je citlivým seismografem časoprostoru, v němž se autorka právě ocitá.

Curtius, jak známo, byl klasický filolog, držel se historicity, sledoval, jak pozdně antické př́iběhy nebo motivy přecházely do literatury středověké a odtud se v literatuře udržovaly po staletí. Je to rovněž př́ípad toposu locus amoenus, který v modifikované podobě nalézáme u Hořké. Motivika locus amoenus zaznívá také z české státní hymny („,Kde domov můj, kde domov můj, voda hučí po lučinách ..."; srov. Locus amoenus 1994), lze jej vlastně charakterizovat 
jako archetypální toužení člověka po něčem čistém, bezstarostném, po ráji, který člověk kdysi v hříchu ztratil. Svým způsobem nemusí být toužení po ráji (zejména v prostředí křest’anském) chápáno za toužení po líbezném místě, locus amoenus, ale za obecný křestanský pocit spojený s návratem do ráje, se snahou každého křest’ana být očištěn.

Odkud se člověk dovídal o ráji? Odkud se o locus amoenus dověděla Hořká? Nebyla renesančně sčetlým a vzdělaným intelektuálem, ale přesto k podobě „líbezného místa" ve svých textech dospěla. Jednak je potřeba uvažovat o tom, že vesnice v její době měla ještě tradiční, křest’anský (přesněji pozdně barokní) charakter života; důležitou roli v ní měl starosta, duchovní (kněz) a učitel. Dlouho se ve vesnickém prostředí a v jeho paměti udržovalo vše to, co s sebou přninášela škola a kostel. Zejména barokní zbožnost a její rezidua zanechala ve vesnickém prostředí výraznou stopu. Někteří badatelé dokonce soudí, že baroko vlastně vytvořilo obraz krajiny, jaký v podstatě známe podnes. Lidská pamět' pak udržovala po desítky, ba stovky let příběhy, s nimiž se lidé začali seznamovat prostřednictvím kancionálových písní a kazatelských projevů. V kázáních byla užívána tzv. exempla, př́íklady, které měly za cíl oživit kázání a přiblížit některou obecnou pravdu běžnému člověku, zživotnit ji a pragmatizovat. Tyto příběhy nebyly dlouhé, často to byl skutečný příklad bez nějaké promyšlené narativní strategie. Nicméně tyto př́iběhy se v lidovém prostředí dlouho pamatovaly a ústním podáním se udržovaly. Pamět' navíc ve folklorním prostředí tyto příběhy rozšiřovala - amplifikovala. (O „narůstání” ve folkloru píše kupř. Mukařovský 1942/1966; situaci si můžeme představit jako by šlo o navlékání korálků, kdy se na nit za jeden korálek přidávají další a další.)

Tyto prŕiběhy pak často opakovali v rozšířené podobě někteří vypravěči ze Slezska ještě ve 20. století. Je nepochybné, že tyto př́iběhy znala rovněž Hořká; zaznamenala tak ve svých knihách vlastně rezidua baroka a př́p. ještě starších kulturněhistorických epoch. Sama navíc byla vypravěčkou - měla narátorský talent, používala výrazné mimiky a originálních gest při vyprávění - tím se zabýval ve folkloru ve Slezsku hodně A. Satke, který od tamějších vypravěčů získal celou kolekci příběhů - z hlediska žánrového šlo většinou o povídky, pohádky nebo humorky (srov. Satke 1984).

\section{Snadný čas a prostor u Hořké}

Již v úvaze o návratech a paměti u Hořké jsme si povšimli tzv. snadného času a prostoru, s nímž se střetáváme zejména $\mathrm{v}$ pohádkách. Pohádkám se teoreticky věnovala zejména ruská věda, např. V. J. Propp nebo D. S. Lichačov, který ve své Poetice staroruské literatury se zabývá, mimo jiné, některými strategiemi užívanými v pohádce. Je to zejména zmíněný tzv. snadný čas a prostor pohádky. S těmito strategiemi se zpravidla setkáváme v prózách Hořké: snadno se ona $\mathrm{v}$ pozici vypravěčky nebo její postavy přemist'ují z jednoho prostoru do jiného, z jednoho času do druhého. Na pozadí pohádkoslovné tradice je třeba chápat její knihy, jinak se nám samozřejmě mohou začít jevit jako nedokonalé 
- nedokonalé z hlediska optiky dnešního čtenáře a badatele. (Je tu třeba více než jinde pracovat s historickou poetikou. Můžeme uvést př́íklady z její prózy Mezivodky, která už názvem vypovídá, že děj se odehrává na pomezí, někde na hranici, mezi dvěma různými světy. Světy rozdílnými národnostně, etnicky, jazykově, sociálně, demograficky atd. atd. Ale také mezi světem skutečným a fikčním, mezi dobrem a zlem, mezi životem a smrtí ... Př́íklady jejího jakéhosi bezčasí či „snadného” času (citace z Hořká 1975):

Dnes už dávno té veliké čtverhranné kaluže ... (s. 10)

Ano, tak tomu tenkrát bylo.

Dávno je tomu, dávno ...

Tenkrát nebyla ještě kolem něho zahrádka.

Kolik jí bylo let, nikdo nevěděl, ona také ne. (s. 11)

\section{$7 \mathrm{Na}$ hranici druhů a žánrů}

Pokud již byl zmíněn žánr, je patřičné v této souvislosti připodotknout, že Hořká sice využívá určitých strategií příznačných pro pohádku, ale píše zejména v žánru, který lze pojmenovat jako balada $v$ próze nebo prozaická balada. Balada podle definice má kořeny již ve středověké taneční písni, ballare znamená tančit, později se stává vyprávěním ve verších o nějaké tragédii, od 20. století ztrácí veršovanou formu a častěji se již s baladou setkáváme v próze (srov. Nejedlá 1973). Posiluje se v jejím ustrojení epická složka, avšak lyrické pasáže i dialogická forma zůstávají přítomny. Zbývá zde ještě kontextově Hořkou zařadit - mezi ostatní autory, kteří psali rovněž baladické příběhy, a ukázat na odstíněné typy balady v próze. Je to žánrová varianta oblíbená mezi českými spisovateli od přelomu 19. a 20. století (Šlejhar, Mrštík aj.) i ve 20. století (Vančura, Čapek, Olbracht, Glazarová, Majerová, Nový aj.) až podnes (Sládková, Körner, Drozd aj.).

\section{Existencialismus sui generis}

Konečně nelze si nepovšimnout, že Hořká podává $\mathrm{v}$ textech své variace na téma domova, jeho obhajoby ve smyslu nenahraditelnosti v lidském životě. Je to př́imo svého druhu imperativ, který ve svých textech nabízí svým čtenářům. Přitom je zvláštní, že nedorostla až $\mathrm{k}$ autorům, kteří se kategorií domova, samoty, vytržení, absurdnosti života apod. zabývali speciálně. Byla přece vrstevnicí autorů tzv. existencialistů (srov. o české podobě existencialismu zejména práci V. Černého 1992 - Druhý sešit o existencialismu). Ale právě tím, že Hořká byla $\mathrm{v}$ př́mém působení a $\mathrm{v}$ blízkosti folkloru, zůstávala mimo dosah všech evropských literárních i filozofických směrů a proudů a jimi v zásadě nedotčena. Jde u ní o totální identifikaci s prostředím, o jeho svojské vnímání i interpretaci. Duchovně se identifikovala s prostředím, v němž žila; svými texty se vlastně do tohoto prostředí vepsala a tento prostor nikdy už nebude myslitelný bez ní a jejích textů. 
I po mnoha studiích a monografiích věnovaných textům Hořké zůstává ještě hodně nezodpovězených otázek. Některé ještě nebyly ani artikulovány, jiné formuluje sama proměněná optika $\mathrm{v}$ době unifikačních tendencí. Jejich širri stačil jen naznačit stručný příspěvek.

\section{LITERATURA}

Petr BOGATYREV, 1971: Souvislosti tvorby. Cesty $k$ strukture lidové kultury a divadla. Ed. Jaroslav Kolár a Bohuslav Beneš. Praha: Odeon.

Václav ČERNÝ, 1992: První a druhý sešit o existencialismu. Ed. Jarmila Víšková. Praha: Mladá fronta.

Locus amoenus - Místo líbezné, 1994. Praha: KLP.

Lumila HOŘKÁ, pozůstalostní fond, Památník Petra Bezruče. Opava (zde korespondence s básníkem V. Holanem).

- -, 1975: Trnité cesty. Mezivodky, Bejatka, Hanys Bejamin. Ed. Jiř́i Svoboda. Ostrava: Profil. 246.

- -, 1992: Tesknice. Ed. Antonín Satke. Karviná: Gramma.

František HALAS - Vladimír HOLAN, 1984: Láska a smrt. Výbor lidové poezie. Ed. J. Opelík. Praha: Odeon.

Dmitrij Sergejevič LICHAČOV, 1971: Poetika staroruské literatury. Přel. Ladislav Zadražil, doslov Světla Mathauserová. Praha: Odeon.

Jan MUKAŘOVSKÝ, 1942/1966: Detail jako základní sémantická jednotka v lidovém umění. Studie z estetiky. Ed. Květoslav Chvatík. Praha: Odeon. 209-222.

Jaromíra NEJEDLÁ, 1973: K problematice baladické tvorby třicátých let. Praha: Univerzita Karlova.

Libor PAVERA, František VŠETIČKA, 2002: Lexikon literárních pojmů. Olomouc: Nakladatelství Olomouc.

Antonín SATKE, 2002: Prozaická ústní slovesnost. Těšínsko. 4 díl. Uspořádal Jaroslav Štika. Šenov u Ostravy: Tilia. 121-218. [Společně s G. Sokolovou.]

- -, 1968: Poezie Ludmily Hořké (K nedožitým 75. narozeninám spisovatelky). Slezský sbornik 66, 342-359.

- -, 1972: L. Hořká, spisovatelka bolestí a nadějí hlučínského lidu. Slezsko 4/ 1-2, $16-19$.

- - (ed.), 1984: Pohádky, povídky a humorky ze Slezska. Studii o lidových pohádkách a jejich vypravěčích napsal, texty shromáždil, k vydání připravil a slovníčkem i poznámkami a př́lohami opatřil A. Satke. Ostrava: Profil.

- -, 1988: Ludmila Hořká a národopis jejího kraje. Vlastivědné listy 14/1, 31-32.

- -, 1990: Z kolední tvorby Ludmily Hořké. Vlastivědné listy 16/ 2, 32-37. 
- -, 1993: Spisovatelka mezi dvěma kulturami. (K 100. výročí narození Ludmily Hořké). Česká literatura 1948-1956. Sborník materiálů z literárněvědné konference 35. Bezručovy Opavy. Red. Vladimír Pfeffer. Opava: SZM-Památník Petra Bezruče a FPF SU. 127-136.

Dorota SIMONIDES, 2006: Europejski kontekst słowackich opowiadań ludowych. Slavista Frank Wollman v kontexte literatúry a folklóru I-II. Ed. Hana Hlôšková a Anna Zelenková. Bratislava - Brno: Ústav etnológie SAV, Slavistická společnost Franka Wollmana v Brně, Česká asociace slavistů, Slavistický ústav Jána Stanislava SAV. 55-65.

Jiří SVOBODA, 1975: Doslov, in Hořká. 241-246.

--, 1974: Tvorba a region. Sedm kapitol o literatuře na Ostravsku. Ostrava: Profil.

Teória literatúry, Výber z ,formálnej metódy“, 1971. Ed. Mikuláš Bakoš. Bratislava: Pravda.

Drahomíra VLAŠÍNOVÁ, 2008: Ludmila Hořká. „Hořký život - hořké jméno“. Portrét spisovatelky Ludmily Hořké. Opava: Matice slezská.

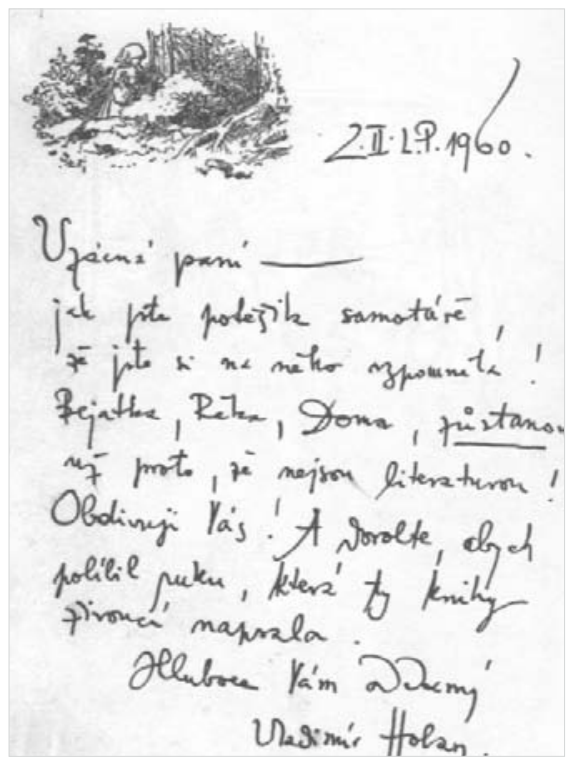

Dopis básníka Vladimíra Holana autorce (uloženo ve fondech Památníku Petra Bezruče, Opava). / The letter of the poet Vladimír Holan to the author (in the collection of Památník Petra Bezruče, Opava). / Pismo pesnika Vladimírja Holana avtorici (zbirka: Památník Petra Bezruče, Opava).

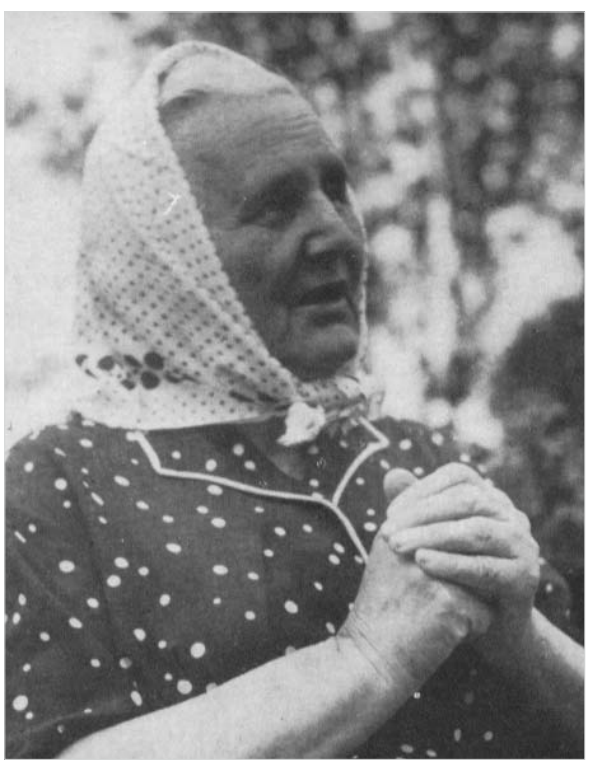

Ludmila Hořká při vyprávění (u narátorů jsou důležité rovněž mimika a gesta). / Ludmila Hořká in the process of narration (narrators value mimicry and gestures). / Ludmila Hořká v času pripovedi (pri pripovedniku je pomemben tudi izraz obraza in kretnje). 


\section{MED FOLKLORO IN UMETNIŠTVOM, MED DRŽAVAMI IN EKSISTENCO}

Pisateljica, organizatorka ljudskih prireditev, zbirateljica folklore in pripovedovalka ljudskih zgodb Ludmila Hořká (1892-1966) je svoje življenje preživela na Hlučinskem. To je v regiji, ki leži na območju dveh nekdanjih cesarstev: pruskega in avstro-ogrskega in se je skozi celo 20. stoletje narodnostno, politično in demografsko pa tudi drugače preoblikovala. Pisateljica je doživela politične prevrate, družinske in naravne tragedije, zelo dobro je spoznala izkušnje malih, a zanimivih ljudi, od katerih se je učila. Svoj dolg je povrnila s shranjevanjem metaforično poimenovane razbeljene lave (kot bi lahko opredelili folkloro). V njeni ustvarjalnosti lahko najdemo elemente lirike, epike in dramatike (svoja besedila - razen poezije - je pisala v žanru balada v prozi), folklore in drugih poskusov umetniške literature. Raziskovalca je zanimal tudi problem locus amoenus v ustvarjalnosti Hořke, njenega avtoliterarnega odnosa do folklore in leposlovja ter motiv za vrnitev. 